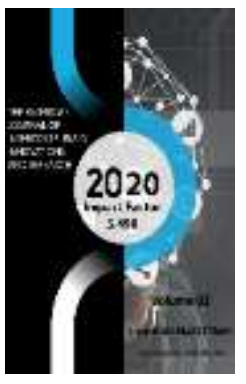

Journal Website: http://usajournalshub.c om/index,php/tajiir

Copyright: Original content from this work may be used under the terms of the creative commons attributes 4.0 licence.

\section{Territorial Aspects Of The Organization Of Ecotourism Routes In The Turkestan Ridge}

\author{
Gudalov Mirkomil \\ Department Of Geography And Fundamentals Of Economics, Uzbekistan \\ Umriniso Lapasova \\ 2nd Year Master's Degree Student In Geography At JSPI, Uzbekistan \\ Gulbahor Umurzakova \\ 2nd Year Master's Degree Student In Geography At JSPI, Uzbekistan
}

Associate Professor, Candidate Of Geographical Sciences, Jizzakh State Pedagogical Institute

\title{
ABSTRACT
}

This article develops scientific recommendations for the development of modern ecotourism in mountainous areas and the definition of directions for eco-routes.

\section{KEYWORDS}

Ecotourism, natural monuments, regional areas, recreational resources, tourist route, Zaamin National Nature Park, wildlife.

\section{INTRODUCTION}

Currently, ecotourism is recognized as the fastest growing sector among the economy. A large influx of international tourists is becoming more and more interested in relaxing in the beautiful and unique nature. For this reason, in recent years, great attention has been paid in our country to the development of ecotourism. In particular, the geographical study of the scientific basis of the territorial organization and development of ecotourism and the organization of promising ecotourism routes in the Turkestan ridge, which has the most beautiful and beautiful nature of Uzbekistan, is of great scientific and practical importance [1. Alibekov L]. 


\section{THE MAIN PART}

The Turkestan ridge is rich in natural monuments and is one of the mountains that stands out from other regions with its picturesque, beautiful nature. The list includes the possibility of organizing a number of tourist routes to get acquainted with the wildlife and recreation in the reserve, national park and forestry and its surroundings. Territorial organization and development of ecotourism in the Turkestan ridge is directly important for the preservation of unique nature, natural monuments and endangered plants and animals.

We believe that in the organization and development of ecotourism in the Turkestan ridge, it is necessary to choose a number of routes. Two of these routes are located in the Zaamin district, and routes from Jizzakh have been developed.

Route 1- It will be organized on the route Jizzakh - Pishagor, and it is advisable to make ecotourism trips through the following facilities.

- Ravot (20 km from the city of Jizzakh);

- Pishagor village (31 km);

- Xatap (35 km);

- Beshbuloq (39 km);

- Khoja Sarob ota shrine (45 km);

- Pishagor cave (49 km).

Along these routes, it is necessary to create conditions for tourists to get acquainted with the Pishagor Cave and its surroundings, as well as special habitats and caves.

Route 2- Jizzakh-Zaamin National Nature Park. The route starts in Jizzakh and includes the Zaamin District Museum of Local Lore,
Bogishamol, Hulkar, Duoba, Ettikechuv, Togterak villages and the Zaamin National Nature Park. This route is $96 \mathrm{~km}$ long.

The construction of grasslands and hotels on the route Jizzakh - Zaamin National Park to get acquainted with the beautiful nature of the region, local conditions and traditions, in short, the creation of tourist infrastructure will further increase the tourism potential of the district.

The presence of ecotourism sites such as Miq Castle, Pishagor Cave, Boboyongoq, historical archeological monuments such as Turtkultepa, Kultepa and Shahristan fortresses on the northern slope of the Turkestan ridge testifies to the high tourist potential of the region. It is also possible to develop folklore and ethnographic tourism, health tourism, ecological tourism, cultural tourism [2. Gudalov $\mathrm{M}]$.

In order to develop tourist routes in the region, it is necessary to conduct an inventory of existing historical sites, to fully explore the potential of service facilities at the sites of historical monuments and along the routes of ecotourism. In particular, it would be expedient to develop business projects on ecotourism [3. Gudalov M]

Road signs in Uzbek, Russian and English should be installed on the roads leading to the natural monuments located on the routes of ecotourism. The organization of ecotourism routes in the region is of great importance, as well as the establishment of service entities for the preservation of roads, historical monuments, repair, maintenance of cleanliness along the routes [4. Gudalov M]. It is also important to build hotels on the roads 
along ecotourism routes, repair existing ones, organize the provision of necessary services in accordance with international standards, take measures to develop infrastructure [5. Gudalov $\mathrm{M}]$.

In the northern part of the Turkestan ridge, there will be no strong changes in the organization of ecotourism, that is separate buildings for hotels, restaurants and similar services will not be built, but tourists will be welcomed in this way. On the basis of this project, the cooperation between the population and nature will be demonstrated, and tourists will be attracted to see this harmony [6. Sharipov Sh].

\section{CONCLUSION}

Zaamin National Park, the main ecotourism center on the northern slope of the Turkestan ridge, carries out the following activities:

- Creation and development of favorable conditions for recreation, organization of domestic and foreign tourism;

- Nature conservation, especially the protection of spruce, rare flora and fauna of special value;

- Creation of the necessary scientific and technical base for the organization and conduct of scientific research on ecotourism;

- To acquaint visitors of the Zaamin National Nature Park with the unique objects of the national park of special value;

The organization of ecotourism in the northern part of the Turkestan ridge is intended to serve not only one-way, but also many-way tourists [7. Sharipov Sh]. For this reason, the following should be taken into account when traveling to enjoy nature for various purposes:
- To get acquainted with the culture, customs and rituals of the peoples living in the region and to ensure their direct participation;

- Taking into account the fact that the peoples living in the region eat the national dishes and, if desired, participate in the preparation process, etc .;

- Grass museums organized for ecotourists in the region can be decorated in accordance with the culture, traditions and spirituality of the local people, giving tourists the opportunity to directly participate in the process of purchasing or preparing various souvenirs.

\section{REFERENCES}

1. Alibekov L, Alibekova S, Hazarov I, Gudalov $M$. About some regularities of degradation geosystems in Central Asia. Tatranka Javorina, Slovakia, 2012, Vol 21, № -1, 42-44 r

2. Gudalov M. Foundation of Aydar-Arnasay lakes system and their effects on the environmental landscape. Nature and Science.Volume 17, Number 11 November 25, 2019 USA New York.

3. Gudalov M., Zikirov B. Methods of studying the landscapes around the Aydar-Arnasay lake system. International engineering journal for research \& development. Vol - 5 , Issue - 7, 2020 India.

4. Gudalov M., Zikirov B., Imamova D. Predicting changes in landscares around the Aydar-Arnasay lake system. Accerted in the journal The American of Engineering and Technology. Volume - 02, Issue - 10, October 2020. 
5. Gudalov M., Gozieva M. Ways to develor modern ecoturism in the Zamin basin. International engineering journal for research \& development. Vol - 5, Issue - 7, 2020 India.

6. Sharipov Sh, Gudalov M, Shomurodova Sh. Geolologic situation in the Aydar-Arnasay colony and its atropny. Journal of Critical Reviews. Volume 7, Issue 3, 2020 Malaysia Kuala Lumpur.

7. Sharipov Sh, Shomurodova Sh, Gudalov M. The use of the mountain kars in the tourism sphere in cort and recreation zone of Chimgan-Charvak. Journal of Critical Reviews. Volume 7, Issue 3, 2020 Malaysia Kuala Lumpur.

8. Omonov, Q., \& Karimov, N. (2020). Importance Of Ancestoral Heritage. The American Journal of Social Science and Education Innovations, 2(09), 196-202.

9. Karimov, N. R. (2020). A True Successor of Great Central Asian Scholars. Journal «Bulletin Social-Economic and Humanitarian Research,(7), 62-69.

10. Turakhanovna, S. U. (2020). The Issue of Literary Heroism in Korean Literature. Solid State Technology, 63(6), 1779-1785.

11. Kariev, A., \& Aminov, H. (2020). New information about Imam al-Zarnūjī and his work "Ta'lim al-Muta'allim". Solid State Technology, 63(6), 2372-2387. 